\title{
A case who died due to the suicidal intake of aluminum phosphide
}

\section{Alüminyum fosfit'in intihar amaçlı alımına bağlı bir ölüim olgusu}

\author{
Uğur DEMIR, Yavuz HEKIMOGLU, Mahmut ASIRDIZER, Yasin ETLI, Erhan KARTAL, Orhan \\ GUMUS
}

Department of Forensic Medicine, Medical Faculty of Yuzuncu Yil University, 65080, Van, Turkey

Corresponding author: Mahmut Aşırdizer MD, Professor, Head of Department of Forensic Medicine, Medical Faculty of Yuzuncu Yil University, Van, Turkey

E-mail: masirdizer@yahoo.com

Received/Accepted: November 07,2016/January 24, 2017

Conflict of interest: There is not a conflict of interest.

\begin{abstract}
SUMMARY
Although it is rarely seen in Turkey and developed countries, aluminum phosphide poisoning is an important heath problem because of its high mortality rate. Aluminum phosphate tablets in $3 \mathrm{~g}$ weight which are sold in the market under the trade name " $57 \%$ Fumiphos" include 57\% aluminum phosphide and 43\% ammonium carbonate. In the present report, it was aimed to define clinical, crime scene investigation and autopsy findings of a case of aluminum phosphide poisoning that was rarely seen in Turkey and comparatively discuss data of our case and literature knowledge. 20 years old male patient, hospitalized with an ambulance following intake of aluminum phosphide while he was in military service and he was accepted as exitus after intense cardio-pulmonary resuscitation efforts. From witness statements, it was learned that patient taken orally a poison; a pill box written "Fumiphos $57 \%$ aluminum phosphide" on it, was found in patient's jacket pocket; and it was learned that patient shared some words about death in social media before the event. In the performed medico-legal autopsy, macroscopic findings were defined and the tissue samples which obtained in autopsy were examined microscopically. In the results of toxicological analysis of samples which obtained in autopsy, it was reported the presence of $14184 \mathrm{ng} / \mathrm{g}$ aluminum in stomach contents and p-toluene sulfonic acid in visceral organ and muscle samples. Macroscopic and microscopic findings which obtained at autopsy was found compatible with non-specific findings which defined in the literature. In the result of evaluation of crime scene, autopsy and toxicological analysis findings, it was decided that the person's death occurred due to aluminum phosphide poisoning. In this case report, forensic-medicine procedures in cases died due to intoxications was emphasized, and a case who died due to aluminum phosphide poisoning that was a condition commonly seen in developing countries, but rarely seen in Turkey and developed countries was presented and precautions against aluminum phosphide poisoning were defined. Additionally, we suggest that macroscopic and microscopic autopsy findings of the present case which is rarely defined in classical literature will be a guide to medico-legal examiners for aluminum phosphide poisoning.
\end{abstract}

Keywords: Aluminum phosphide, Poisoning, Suicide, Autopsy, Toxicology.

\section{ÖZET}

Alüminyum fosfit zehirlenmesi Türkiye ve gelişmiş ülkelerde nadir görülmesine rağmen yüksek ölüm oranı nedeniyle önemli bir sağlık sorunudur. “\% 57 Fumiphos” ticari ad altında piyasaya sürülen, 3 g ağırlığındaki alüminyum fosfat tabletleri \% 57 alüminyum fosfit ve \% 43 amonyum karbonat içermektedir. Bu makalede, Türkiye'de nadir görülen bir alüminyum fosfit zehirlenmesi olgusunun klinik, olay yeri inceleme ve otopsi bulgularının tanımlanması ve olgumuzun verileri ile literatür bilgilerinin karşılaştırmalı olarak tartışılması amaçlanmıştır. 20 yaşındaki erkek olgu, askerlik görevini yaparken, alüminyum fosfit alımını takiben ambulans ile hastaneye kaldırılmış ve yoğun kardiyo-pulmoner resusitasyon çabaları sonrası ex olarak kabul edilmişti. Tanık ifadelerinden, hastanın ağız yoluyla kutusunun üzerinde "Fumiphos 57\% aluminum phosphide" yazan ve hastanın ceket cebinde bulunan bir zehir aldığı, sosyal medyada ölüm hakkında bazı ifadeler paylaştığı öğrenilmişti. Uygulanan adli otopside makroskobik bulgular tanımlanmış, otopside elde edilen doku örnekleri mikroskobik olarak incelenmişti. Otopside elde edilen örneklerin toksikolojik analiz sonuçlarında, mide içeriğinde $14184 \mathrm{ng} / \mathrm{g}$ alüminyum bulunduğu, iç organ ve kas örneklerinde p-tolüen sülfonik asit saptandığı rapor 
edilmişti. Otopside elde edilen makroskopik ve mikroskopik bulgular, literatürde tanımlanan non-spesifik bulgular ile uyumlu bulunmuștu. Suç mahalli, otopsi ve toksikolojik analiz bulgularının değerlendirilmesi sonucunda, kişinin ölümünün alüminyum fosfit zehirlenmesi nedeniyle meydana geldiğine karar verilmişti. Bu olgu sunumunda, zehirlenme şüphesi olan olgularda uygulanması gereken adli tıp prosedürüne dikkat çekilmiş, gelişmekte olan ülkelerde yaygın olarak görülen ancak Türkiye'de ve gelişmiş ülkelerde nadir görülen bir durum olan, alüminyum fosfit zehirlenmesinden ölen bir olgu sunulmuş ve alüminyum fosfit zehirlenmesine karşı alınacak önlemler tanımlanmıştır. Ayrıca klasik literatürde nadiren tanımlanmış olan mevcut olgunun makroskopik ve mikroskopik bulgularının adli tıp araştırmacılarına alüminyum fosfit zehirlenmesi için rehber olacağını düşünmekteyiz.

Anahtar Sözükkler: Alüminyum fosfit, Zehirlenme, İntihar, Otopsi, Toksikoloji.

\section{INTRODUCTION}

In many agricultural countries, aluminum phosphides which are highly toxic are commonly used in rodenticides, insecticides and disinfectants 1-3. The cause of widespread usage in agriculture sector, especially in grain storage facilities is associated with their lower costs ${ }^{4}$. Aluminum phosphides have been marketed with various trade names worldwide.

Pills with trade name of Phostoxin which have been marketed in Iran, $3 \mathrm{~g}$ weight of each tablet, contain $56 \%$ aluminum phosphide and $44 \%$ ammonium carbonate ${ }^{5}$. In India which have higher incidence of aluminum phosphide intoxications than mean incidence in the world, pills with trade name of Celphos and Quickphos, $3 \mathrm{~g}$ weight of each tablet, contain 56\% aluminum phosphide and 44\% ammonium carbonate, also ${ }^{6}$. In Turkey, pills with trade name of $57 \%$ Fumiphos, $3 \mathrm{~g}$ weight of each tablet, include $57 \%$ aluminum phosphide and $43 \%$ ammonium carbonate ${ }^{7}$. Whereas aluminum phosphide intoxication is one of the main health problems in the developing countries such as Iran and India, it has been rarely seen in European Countries due to strict countermeasures to be easily available in the market of these chemical compounds ${ }^{5,6,8-10}$.

Also, aluminum phosphide intoxication is rarely seen in Turkey. Because the sales of aluminum phosphides is prohibited in the open markets and their sales by authorized companies are under control. Thus, the number of death cases due to aluminum phosphide intoxication is limited in Turkish literature ${ }^{\mathbf{1 1}, \mathbf{1 2}}$.

Aluminum phosphide intoxication is very lethal. Anand et al. reported that ${ }^{6}$, the mortality rate of aluminum phosphide intoxication was between $37 \%$ and $100 \%$, and the mortality rate was found above $60 \%$ even in health centers which have much experience and well equipment. In a study performed by Jaiswal et al. ${ }^{9}$, mortality rate was reported as $69.6 \%$ in 112 patients hospitalized in intensive care center due to intake of aluminum phosphide.

The oral intake of aluminum phosphides is generally $(76 \%-100 \%$ of them $)$ suicidal, uncommonly accidental and rarely homicidal ${ }^{4,13}$.

In the present report, it was aimed to define clinical, crime scene investigation and autopsy findings of a case of aluminum phosphide poisoning that was rarely seen in Turkey and comparatively discuss data of our case and literature knowledge.

\section{CASE}

20 years old male patient, hospitalized with an ambulance following intake of aluminum phosphide while he was in military service and he was accepted as exitus after intense cardiopulmonary resuscitation efforts which lasted 120 minutes.

According to witness statements, patient screamed "My commander, help me, I'm dying' while lying on the ground in the garden of garrison before he hospitalized. His consciousness was evaluated as confused. He said "I swallowed a poison" when asked several times what happened. There were an irritating odor and vomit stains in the crime scene. In jacket pocket of patient, a pill box written "Fumiphos 57\% aluminum phosphide" on it was found. There were 17 complete tablets and small pieces of several tablets which have an irritating odor in the pill box (Figure 1). In the crime scene investigation, it was learned that patient shared some quotes about death in social media before the event (Figure 2).

In the performed medico-legal autopsy, there was not any traumatic injury on the corpse. Pupils was dilated. There was petechial hemorrhages and ecchymosis $2.5 \times 1 \mathrm{~cm}$ in size under the scalp (Figure 3). The weight of brain, cerebellum and brain stem was 1300 gram. Macroscopic appearance of brain was edematous (Figure 4). There was white froth in respiratory tracks. Lungs were edematous and hyperemic (Figure 5). $100 \mathrm{cc}$ serous fluid was seen in the abdominal cavity. There were submucosae hemorrhages in stomach (Figure 6). There was not any pathological finding in other organs except hyperemia. Blood, cardiac blood, bladder lavage, stomach content, liver, kidney, muscle (a piece of musculus iliopsoas), bile, vitreous fluid samples was obtained from 
corpse for toxicological analysis and liver, heart, brain, kidney, lung and stomach samples was obtained for microscopic examination.

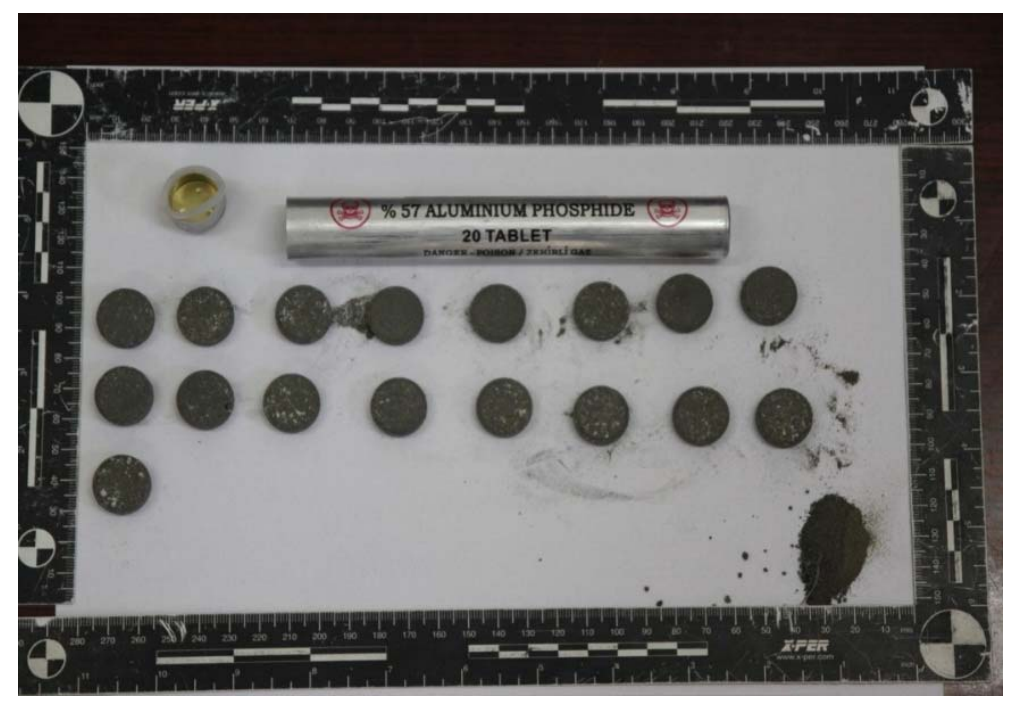

Figure 1. 17 complete tablets and small pieces of several tablets in a pill box written "Fumiphos $57 \%$ aluminum phosphide" on it, which was found in the jacket pocket of patient

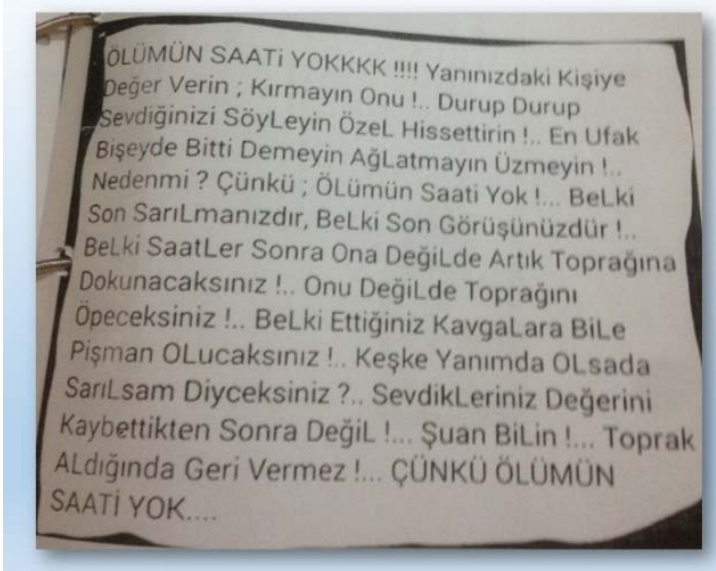

THERE ISN'T SUCH A THING "TIME OF DEATH". Take care of the person next to you. Do not hurt him. Without rhyme or reason, Say that you love them. Make them feel special. Do not say it's over with the slightest reason. Do not make them cry and upset. Do you know why? Because there isn't such a thing "time of death". Maybe it is your last hug. Maybe it is the last time you saw them. After a couple hours, maybe you will touch to his/her grave whilst you cannot touch him/her. You will kiss his/her grave whilst you cannot kiss him/her. Perhaps you will regret from your fights with him/her. You will say that I wish he/she is with me and I wish hug him/her.

Appreciate your loved ones at the present time, not after you lost them. Grave don't give back once it took. BECAUSE THERE ISN'T SUCH A THING “TIME OF DEATH”.

Figure 2. Some Turkish quotes shared by victim about death in social media and its translation to English

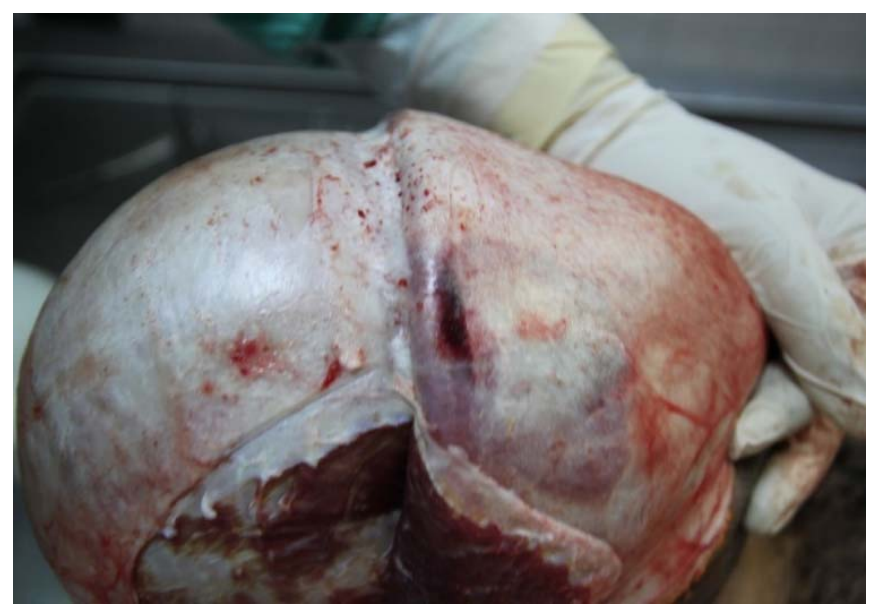

Figure 3. Petechial hemorrhages and ecchymosis under the scalp 


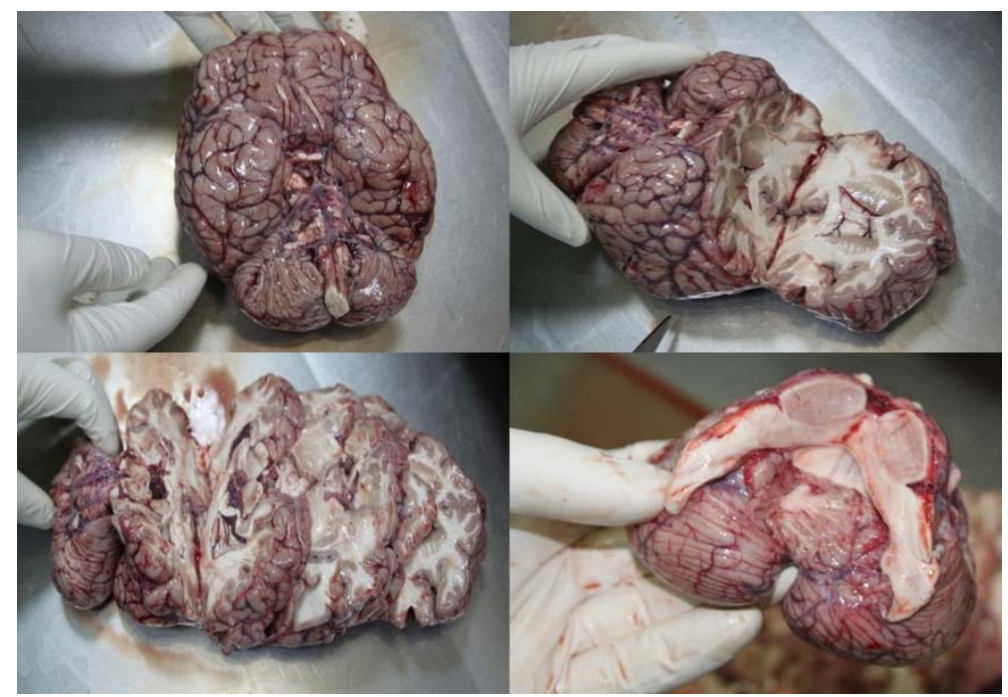

Figure 4. Macroscopic edematous appearance of brain

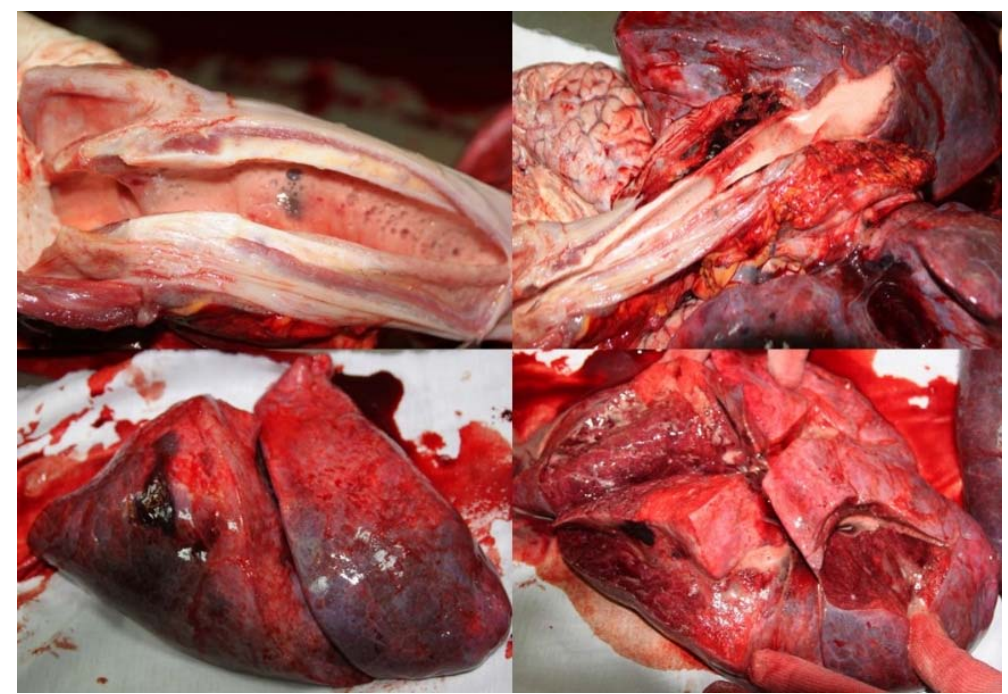

Figure 5. White froth in respiratory tracks and edematous and hyperemic appearance of lung

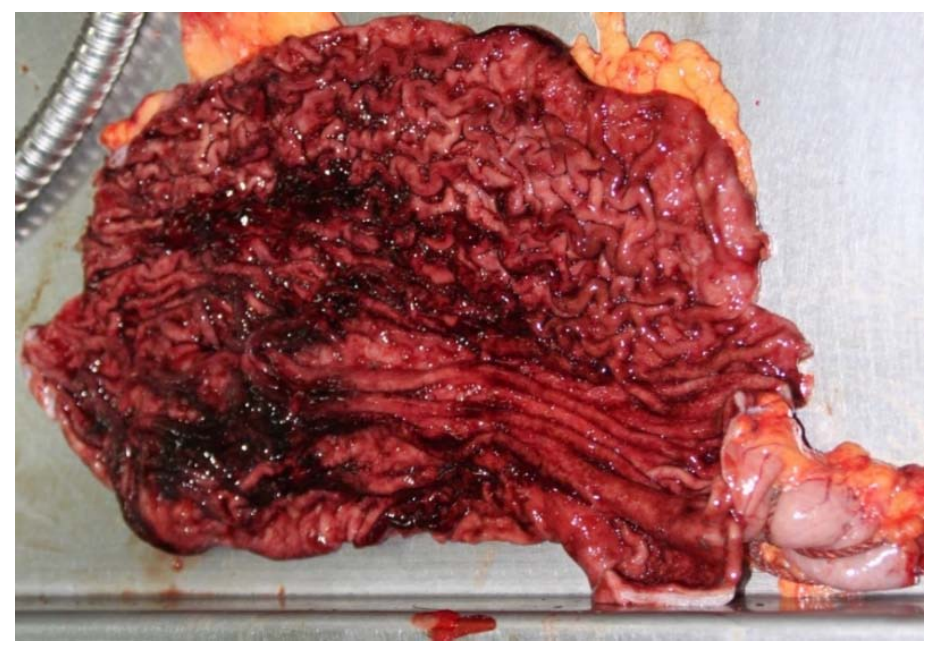

Figure 6. Submucosae hemorrhages in stomach 
In the microscopic examination report prepared by Mortuary Section of Council of Forensic Medicine, it was recorded that there were subendocardial and intramyocardial focal hemorrhages in heart sample, diffuse edema, intra-alveolar hemorrhages, and grade-1 fat embolism findings in lung sample, centrilobular light microvesicular steatosis and subcapsular hemorrhage areas in liver sample, and submucosae hemorrhages in stomach sample.

According to toxicological analysis report issued by Toxicology Section of Council of Forensic Medicine, $14184 \mathrm{ng} / \mathrm{g}$ aluminum was found in stomach contents and p-toluene sulfonic acid in visceral organ and muscle samples.

Public prosecutor asked for medico-legal report from Forensic Medicine Section of Medical Faculty of Yuzuncu Yil University about the cause of death and findings accompanied to death.

In the conclusion section of the medico-legal report, we stated that 1) cause of death was associated with aluminum phosphide intoxication, 2) aluminum which was found in stomach contents and reported in toxicological analysis was an active ingredient of pesticides entitled "Fumiphos 57\% aluminum phosphide", 3) p-toluene sulfonic acid which was found in visceral organ and muscle samples and reported in toxicological analysis was a substance which had been used in manufacturing of corrosion inhibitors, anti-scaling agents, building and construction materials, furniture cleaning and maintenance products, fabric, textile and leather products and intermediate products, perfuming agents, paint agents, coating additives. It is a water-soluble acid that it is detectable in the chalky and dirty water, and it can enter the body by inhalation and dermal contact depending occupation and living environment of person, 4) Grade-1 fat embolism findings in lung was associated with cardio-pulmonary resuscitation efforts which lasted 120 minutes.

\section{DISCUSSION}

Toxic dose of aluminum phosphide is approximately $150-500 \mathrm{mg}{ }^{\mathbf{1 , 5}, 14}$ and lethal dose is approximately 1-1.5 $\mathrm{g}$ in oral intake ${ }^{\mathbf{1 , 2}}$.

Aluminum phosphide intoxication was generally occurred in young males. Jaiswal et al. reported that ${ }^{9}, 70 \%$ of cases exposed to aluminum phosphide poisonings was male patients in their twenties of age. In the study of Soltaninejad et al ${ }^{\mathbf{1 0}}$, $85 \%$ of 956 aluminum phosphide poisoning cases were between 12 and 40 years of age. The present case was 20 years old and male, and this finding was compatible by literature knowledge.
Following the exposure to aluminum phosphide, this compound quickly absorbed by inhalation, or from skin and gastrointestinal tract. Aluminum phosphide reacts with air, water or gastric acid and liberates phosphine gas $\mathbf{1 , 5}$. This gas which is colorless and have an odor like garlic or decaying fish causes the inhibition of respiration following inhibition of cytochrome $\mathrm{C}$ oxidase, the occurrence of myocardial energy deficit and the formation of reactive oxygen compounds due to lipid peroxidation. All these effects cause to changes in cardiac transmembrane action potentials, and finally death occurs 5,15. Corrosive effect of phosphine gas is seen in gastrointestinal tract as hematemesis, sometimes, after two weeks following the exposure, gastroduodenitis and esophageal stricture can be seen in patients with endoscopy or in autopsied corpses ${ }^{15}$. Additionally, intravascular hemolysis and methemoglobinemia can be rarely seen in some cases ${ }^{15}$. In aluminum phosphide intoxication, several clinical findings and symptoms are seen due to multiple organ involvement. In these cases, anxiety, excitation, cough, feeling of chest pressure, headache, dizziness, drowsiness, lethargy, anorexia, nausea, vomiting, dyspnea, retrosternal and epigastric pain was defined as symptoms in early period. Rarely, diarrhea can be observed in this period ${ }^{14-16}$. After affecting cardiovascular system, slimming pulse, arrhythmia, tachycardia, metabolic acidosis accompanied by hypotension, various ECG changes (such as ST elevation/depression, ORS and PR interval prolongation, complete heart block, fibrillation), treatment-resistant shock and peripheral circulatory disorders are some of clinical findings in aluminum phosphide intoxication ${ }^{\mathbf{9}, 14}$. Due to affecting the respiratory system, tachypnea, dyspnea, crepitation, rhonchi and pulmonary edema are commonly seen ${ }^{\mathbf{1 4}, 15}$. It was reported that hemorrhage, acute renal failure, disseminated intravascular coagulation, delirium and coma, methemoglobinemia, adrenal insufficiency, hepatic failure and acute renal failure are other common complications of aluminum phosphide intoxication ${ }^{14,16}$.

In the treatment of aluminum phosphide intoxication, clinicians is obligated to prefer the symptomatic treatment due to absence of specific antidote. However, it was reported that this symptomatic treatment is insufficient on the survival rate when aluminum phosphide is taken over dose above $1.5 \mathrm{~g}^{2,6}$. It was suggested that, precautions against the life threatening conditions such as metabolic acidosis, arrhythmias, acute respiratory distress syndrome and shock, and the early hemodialysis are necessary for decreasing the 
mortality rates ${ }^{\mathbf{1 1}}$. ASN-acetylcysteine use which have cellular regenerative properties and antioxidant effects, and usage of glutathione and magnesium are some of recommended treatment methods ${ }^{2}$. Anger et al reported that firstly symptomatic treatment, neutralization with gastric lavage and potassium permanganate application and intravenous application of magnesium sulfate for antioxidant effects is suggested in early treatment period ${ }^{17}$. Additionally, it was reported that using atropine, pralidoxime and magnesium would decrease morbidity and mortality in aluminum phosphide intoxication ${ }^{15}$.

Emerging of any of the cardiac arrhythmia, refractory shock development, seizures similar to asthma, acute respiratory distress syndrome, aspiration pneumonia, anemia, metabolic acidosis, electrolyte imbalance, coma, severe hypoxia, gastrointestinal hemorrhage and pericarditis in the term following the aluminum phosphide intoxication are accepted as poor prognosis criteria $6,16,18$

Lack of knowledge about action mechanism and kinetics and absence of specific antidote are most important factors in the high mortality rate due to aluminum phosphide intake ${ }^{7,11}$. Hypokalemia which effects the mortality rate is commonly seen in aluminum phosphide poisonings and it probably develops secondary to vomiting. During the aluminum phosphide intoxication, metabolic acidosis, mixed metabolic acidosis, respiratory alkalosis, acute renal failure and permanent and severe hypoglycemia may occur and they cause poor prognosis ${ }^{15}$. It was reported that there was leukopenia in cases following intoxication ${ }^{16}$. Also, increased cardiac stress can cause sudden cardiac deaths, and increased oxygen need and metabolic acidosis may worsen the clinical course ${ }^{19}$.

Death following aluminum phosphide intoxication, is generally due to arrhythmias in the first 24 hours, and shock, acidosis, acute respiratory distress syndrome and arrhythmia after 24 hours ${ }^{6}$. In these cases, cause of death varies from person to person, because death is not associated with only one factor, it is multifactorial. It was reported that death of an adult male is due to acute hepatic failure and encephalopathy whilst is due to encephalopathy and acute renal failure in a case of 12 years old girl 15 .

In the present case, we thought that collective effects of cardiac arrest and pulmonary edema which were developed due to aluminum phosphide intake played major roles in the death. However, we could not evaluate the role of other clinical factors because of lack of laboratory analysis at hospital which was due to died entrance.

P-toluene sulfonic acid detected in visceral organs and muscles was reported in the toxicological analysis report, might be used in manufacturing corrosion inhibitors, anti-scaling agents, building and construction materials, furniture cleaning and maintenance products, fabric, textile and leather products and intermediate products, perfuming agents, paint agents, coating additives. It is a watersoluble acid that it is detectible in the chalky and dirty water, and it can enter the body by inhalation and dermal contact depending occupation and living environment of person ${ }^{20}$. This information was written to medico-legal report, too. In this medico-legal report, we avoided from certain comment because any evidence was not defined in witness statements and crime scene investigation report.

In the corpses of persons who died due to aluminum phosphide intoxication, it may be smelled an odor like garlic or decaying fish on the skin and in oral cavity; it may be seen bluish discoloration on the face and bloody-foamy liquid around of nares ${ }^{19}$. At the autopsy of these cases, nonspecific findings such as subpleural petechial hemorrhages, pulmonary interlobular edema, pulmonary congestion, pulmonary alveolar thickening, dilation of the capillaries in the lungs, cardiac congestion and focal myocardial necrosis, necrosis and edema in the gastric mucosa, especially in the fundus, thinning of the stomach wall, hemorrhagic necrosis and congestion in the adrenal glands, congestion and mild fatty degeneration of the liver, congestion in the kidneys, congestion and necrosis in the spleen may be macroscopically seen ${ }^{\mathbf{1 9 , 2 1 , 2 2}}$. In the microscopic examination, hemorrhagic necrosis and congestion in the adrenal gland, central congestion, degenerative sinus dilation, hemorrhage and mild fatty degeneration in the liver, congestion, infiltration, degeneration and acute swelling in the kidneys, congestion and necrosis in the spleen, the brain necrosis and congestion, alveolar thickening, dilated capillaries and hemorrhage in the lung, pulmonary edema, congestion and hemorrhage in the stomach are findings ${ }^{\mathbf{1 9}}$. Many of these findings was seen in the present case, too. Additionally grade I fat embolism in the lung was detected in this case. Also, it was reported that fat embolism may be associated with cardiopulmonary resuscitation in the literature ${ }^{23}$. We stated that Grade-1 fat embolism findings in lung in the present case was associated with cardio-pulmonary resuscitation efforts which lasted 120 minutes in the medico-legal report. 
For prevention of occurrence of aluminum phosphide poisonings the use of an air-tight containers and protective clothing against chemicals is very important measures ${ }^{\mathbf{1 1 , 1 5}}$.

It was reported that controlled sales of aluminum phosphide and education of farmers who have exposure risk to aluminum phosphide and pesticides are major precautions for minimizing the risk of aluminum phosphide intoxications. Also, educational efforts against suicidal attempts will reduce the number of suicides with aluminum phosphide ${ }^{24}$.

When macroscopic autopsy findings, each of which may be individually effective on death is determined, the evaluation of these findings as single cause of death is one of the mistakes that can be made in the forensic applications.

In the death cases due to intoxications only routine toxicological analysis will not be sufficient for determination of real cause of death because the number of toxicological substances analyzed in the systematical toxicological analysis is limited due to laboratory facilities. In this situation, the toxicological analysis appropriate to target according to the data obtained from crime scene investigation and witness statements will be more important for determination of cause of death.

In the death cases who was doubted from intoxications, recording of all of toxic substances which is suspected detected in crime scene, autopsy application in all cases, careful macroscopic examination during autopsies, the preparation of more number of pathologic samples and toxicological analysis which was applied in more extensive spectrum are basics of medico-legal evaluation for access to the accurate diagnosis.

In this case report, a case who died due to aluminum phosphide poisoning that was a condition commonly seen in developing countries, but rarely seen in Turkey and developed countries was presented and precautions against aluminum phosphide poisoning were defined. Additionally, it was thought that this literature knowledge placed in this case report about macroscopic and microscopic autopsy findings which rarely defined in classical literature will be guide to medico-legal examiners for aluminum phosphide poisoning.

\section{REFERENCES}

1. Gurjar M, Baronia AK, Azim A, Sharma K. Managing aluminum phosphide poisonings. J Emerg Trauma Shock 2011; 4: 378-84.

2. Bogle RG, Theron P, Brooks P, Dargan PI,
Redhead J. Aluminium phosphide poisoning. Emerg Med J 2006; 23: e3.

3. Address:

https://en.wikipedia.org/wiki/Aluminium_ phosphate. Retrieved: July 14, 2016.

4. Mostafazadeh B. Aluminium Phosphide Poisoning. In: Acree W (ed). Toxicity and drug testing. $1^{\text {st }}$ ed. Rijeka: InTech, 2012: pp 345-60.

5. Shadnia S, Soltaninejad K, HassanianMoghadam H, Sadeghi A, Rahimzadeh H, Zamani N, Ghasemi-Toussi A, Abdollahi M. Methemoglobinemia in aluminum phosphide poisoning. Hum Exp Toxicol 2011; 30: 250-3.

6. Anand R, Binukumar BK, Gill KD. Aluminum phosphide poisoning: an unsolved riddle. J Appl Toxicol 2011; 31: 499-505.

7. Address:

http://www.agrifum.com/dosyalar/fumiph os_msds.pdf. Retrieved: July 14, 2016.

8. Mehrpour O, Jafarzadeh M, Abdollahi M. A systematic review of aluminium phosphide poisoning. Arh Hig Rada Toksikol 2012; 63: 61-73.

9. Jaiswal S, Verma RK, Tewari N. Aluminum phosphide poisoning: effect of correction of severe metabolic acidosis on patient outcome. Indian J Crit Care Med 2009; 13: 21-4.

10. Soltaninejad K, Nelson LS, Bahreini SA, Shadnia S. Fatal aluminum phosphide poisoning in Tehran-Iran from 2007 to 2010. Indian J Med Sci 2012; 66: 66-70.

11. Hakimoglu S, Dikey I, Sari A, Kekec L, Tuzcu K, Karcioglu M. Successful management of aluminum phosphide poisoning resulting in cardiac arrest. Turk J Anaesthesiol Reanim 2015; 43: 288-90.

12. Altintop I, Kaynak MF. A race against time in lethal aluminum phosphide intoxication: a case report. Medicine Science 2016; 5(Suppl 1): 143-5.

13. Singh UR, Tiwari S, Garg SP, Kuriakose L. A study of histopathological changes in viscera in aluminium phosphide poisoning. International Journal of Recent Advances in Multidisciplinary Research 2015; 2: 141-4.

14. Moghadamnia AA. An update on toxicology of aluminum phosphide. Daru. 
2012; 20: 25.

15. Proudfoot AT. Aluminium and zinc phosphide poisoning. Clin Toxicol (Phila) 2009; 47: 89-100.

16. Ntelios D, Mandros C, Potolidis E, Fanourgiakis P. Aluminium phosphideinduced leukopenia. BMJ Case Rep. 2013; 2013. pii: bcr2013201229.

17. Anger F, Paysant F, Brousse F, Le Normand I, Develay P, Gaillard Y, Baert A, Le Gueut MA, Pepin G, Anger JP. Fatal aluminum phosphide poisoning. J Anal Toxicol 2000; 24: 90-2.

18. Guner U. Toxicology. Edirne: Trakya University Science Faculty, 2014.

19. Bumbrah GS, Krishan K, Kanchan T, Sharma M, Sodhi GS. Phosphide poisoning: a review of literature. Forensic Sci Int 2012; 214: 1-6.

20. Address:https://pubchem.ncbi.nlm.nih.gov /compound/p-

toluenesulfonic_acid\#section=Top.

Retrieved: July 14, 2016.

21. Jain AK, Nigam M, Garg SD, Dubey BP, Arora A. Aluminium phosphide poisoning, autopsy findings. JIAFM 2005: 27: 35-9.

22. Etemadi-Aleagha A, Akhgari M, Iravani FS. Aluminum phosphide poisoningrelated deaths in Tehran, Iran, 2006 to 2013. Medicine (Baltimore) 2015; 94: e1637.

23. Krischer JP, Fine EG, Davis JH, Nagel EL. Complications of cardiac resuscitation. Chest 1987; 92: 287-91.

24. Chaudhary S, Momin SG, Vora DH, Modi P, Chauhan V, Chotaliya D.An epidemiological study of fatal aluminium phosphide poisoning at Rajkot. IOSR Journal of Pharmacy 2013; 3: 17-2. 